\title{
Ecology and diversity of Mediterranean hard-bottom Syllidae (Annelida): a community- level approach
}

\author{
Luigi Musco* \\ Laboratorio di Zoologia e Biologia Marina, CoNISMa, DiSTeBA, Università del Salento, 73100 Lecce, Italy \\ Present address: Laboratorio di Ecologia Marina, CNR-IAMC, Via G. Da Verrazzano 17, 91014 Castellammare del Golfo, \\ Trapani, Italy
}

\begin{abstract}
The Syllidae are geographically widespread polychaetes, particularly diverse and abundant on marine hard bottoms and in seagrass meadows. Hydrodynamics, habitat complexity and biological traits are hypothesized to influence syllid bathymetric distribution. Little is known about the consistency of, or variation in, horizontal distribution patterns with varying depth. I analyzed hard-bottom Syllidae at 2 depths $(1.5$ and $5 \mathrm{~m})$ at the scale of 1000s of metres, located around the Torre Guaceto marine protected area (MPA) (SE Italy) in order to (1) quantify syllid diversity and abundance, (2) describe their distribution pattern and (3) identify potentially important factors influencing their distribution. The Syllidae were dominant and highly diverse, and new biogeographic records were reported. Horizontal distribution patterns changed with depth, being more variable at 1.5 than $5 \mathrm{~m}$. The presence of the MPA had little effect on alongshore variation in individual species abundance and assemblage structure. Contrary to expectations, there was no consistent relationship between Syllidae distribution and habitat-forming algal species. In contrast, syllid abundance varied with that of other invertebrates, suggesting that future research should focus on the role of interspecific interactions in syllid ecology. Syllidae are a highly diversified and widespread taxon that deserves special attention when analyzing biodiversity patterns of hard-bottom benthic communities.
\end{abstract}

KEY WORDS: Polychaete $\cdot$ Marine Protected Area $\cdot$ Covariables $\cdot$ Alongshore variation $\cdot$ Vertical distribution · DISTLM-forward · PERMANOVA

\section{INTRODUCTION}

Syllidae (Annelida) is one of the dominant polychaete Families in hard-bottom benthic communities, showing remarkable abundance and morphofunctional diversity, particularly in feeding habits and reproductive biology (Giangrande et al. 2000, Çinar \& Ergen 2002, Musco et al. 2010). These small to medium-sized vagile worms are quite common in shallow subtidal algal communities and seagrass meadows (San Martín 2003). Structurally complex coralline algae area suitable habitat for the Syllidae (Tena et al. 2000, Serrano et al. 2006). Syllid species composition, however, appears almost unrelated to algal cover, suggesting the absence of habitat-specific associations (Giangrande et al. 2003). In general, it is suggested that the Syllidae should be abundant wherever a 3-dimensional substrate provides suitable microhabitats for settlement (Abbiati et al. 1987, Giangrande 1988).

Hydrodynamics play a key role in structuring the hard-bottom polychaete assemblages, especially in shallow waters (Fresi et al. 1983, 1984), and this also applies to the Syllidae. Giangrande (1990) hypothesized that in the zone between 0 and $2 \mathrm{~m}$ depth, physical factors play a dual role in the vertical distribution of syllids: (1) a direct effect through the provision of a refuge habitat in which physical stress 
reduces the intensity of competition and (2) an indirect effect whereby the physical stress influences the distribution of the sessile macrobenthos forming the syllid habitat. In the direct effect, reproductive biology is thought to to play a major role, with physically stressed shallow-water communities preferentially hosting syllid species that reproduce continuously. However, little is known about syllid biology and even less is known about the interspecific interactions that might be of key importance in structuring syllid assemblages (Çinar \& Gönlügür-Demirci 2005, Serrano et al. 2006, Musco et al. 2009). For example, predation is thought to structure some syllid assemblages in seagrass meadows by limiting species dominance and enhancing diversity (Gambi et al. 1995). Further studies examining the relations between syllid assemblages and their habitats are necessary to fill gaps in our knowledge of syllid ecology.

The analysis of species distribution at multiple spatial scales is increasingly common in marine ecology (e.g. Anderson \& Millar 2004, Fraschetti et al. 2005a), but in recent years emphasis has been on establishing whether the same or different patterns of alongshore variability occur at different depths (Benedetti-Cecchi 2001, Terlizzi et al. 2007). Analysis of Polychaeta distribution in the south Adriatic area (Mediterranean Sea) reveals a high degree of horizontal (i.e. alongshore) variation in assemblages at the scale of 100s of kilometres (Fraschetti et al. 2002). In the same geographic area, Giangrande et al. (2003) observed both (1) vertical variation in polychaete assemblages from 5 to $25 \mathrm{~m}$ depth and (2) horizontal differences at a scale of 100 s of metres, with variation increasing with decreasing depth. In both of these studies the Syllidae are thought to be the major taxon responsible for the observed patterns. Diversity indexes of north Adriatic Syllidae showed differences in syllid assemblages across depth and significant horizontal variation among transects 100s of metres apart, although total abundance does not change (Mikac \& Musco 2010). Alongshore variation in syllid abundance and distribution at a depth of $4 \mathrm{~m}$ is more evident at a scale of 100 s of metres than that of 1000s of metres at a Northern Ionian location in the Mediterranean Sea (Musco et al. 2009). These findings suggest that variation across depths should be most easily identified at the spatial scale of 1000s of metres, where alongshore variability is negligible. Overall, the vertical patterns of syllid abundance and distribution (1 to $5 \mathrm{~m}$ depth), and the consistency or variation in these patterns, remain poorly studied.

Fluctuations in abiotic conditions are usually large in shallow subtidal habitats, with important conse- quences for species assemblages (e.g. Witman \& Dayton 2001). In addition, human activities may further enhance the level of stress to which the assemblages are exposed. This also applies to polychaete assemblages, and especially to the Syllidae, which appear to be particularly sensitive to several forms of anthropogenic disturbance (e.g. trampling and sewage discharge) (Giangrande et al. 2003, 2005, Musco et al. 2004, Musco \& Giangrande 2005, Casu et al. 2006, Musco et al. 2009).

Indiscriminate illegal fishing of the date mussel Lithophaga lithophaga has occurred on the Southeast Italian coast, especially in recent decades; the procedure involved the mechanical removal of macrobenthos on calcarenitic rocky bottoms, and although it is now more effectively controlled, it resulted in widespread desertification (barrens) that is still evident (Fanelli et al. 1994). The Marine Protected Area (MPA) of Torre Guaceto (south Adriatic Sea) is much less affected by desertification, probably due to the top-down control of the protected ichthyofauna on grazers inducing a positive cascading effect on the sessile macrobenthos (Guidetti 2006). The area around Torre Guaceto was chosen for the present study because it is characterized by high levels of syllid diversity and abundance (Giangrande et al. 2004).

Here, I analyzed the distribution pattern of the hard-bottom Syllidae in the shallow subtidal zone at Torre Guaceto in order to (1) quantify the diversity and abundance of syllid assemblages, (2) describe their horizontal patterns of distribution at the scale of 1000 s of meters and assess whether these patterns are consistent between 1.5 and $5 \mathrm{~m}$ depth and (3) reveal the variation in syllid assemblages in relation to the most relevant biotic components of the habitat.

\section{MATERIALS AND METHODS}

\section{Sampling area}

Most of the study area fell within the boundaries of the Torre Guaceto MPA, encompassing about $8 \mathrm{~km}$ of coast along the northern Salento Peninsula (southeast Italy) (Fig. 1).

The coast is generally low-lying with a variable profile. The coastline is made up of clay cliffs in the south; moving northwards these become sandy beaches, a small rocky prominent peninsula in the central part, and finally rocky coves alternating with sandy beaches and rocky plateaus in the north. Rocky islets are present in the central and southern parts of the MPA. The calcarenitic rocky plateau 


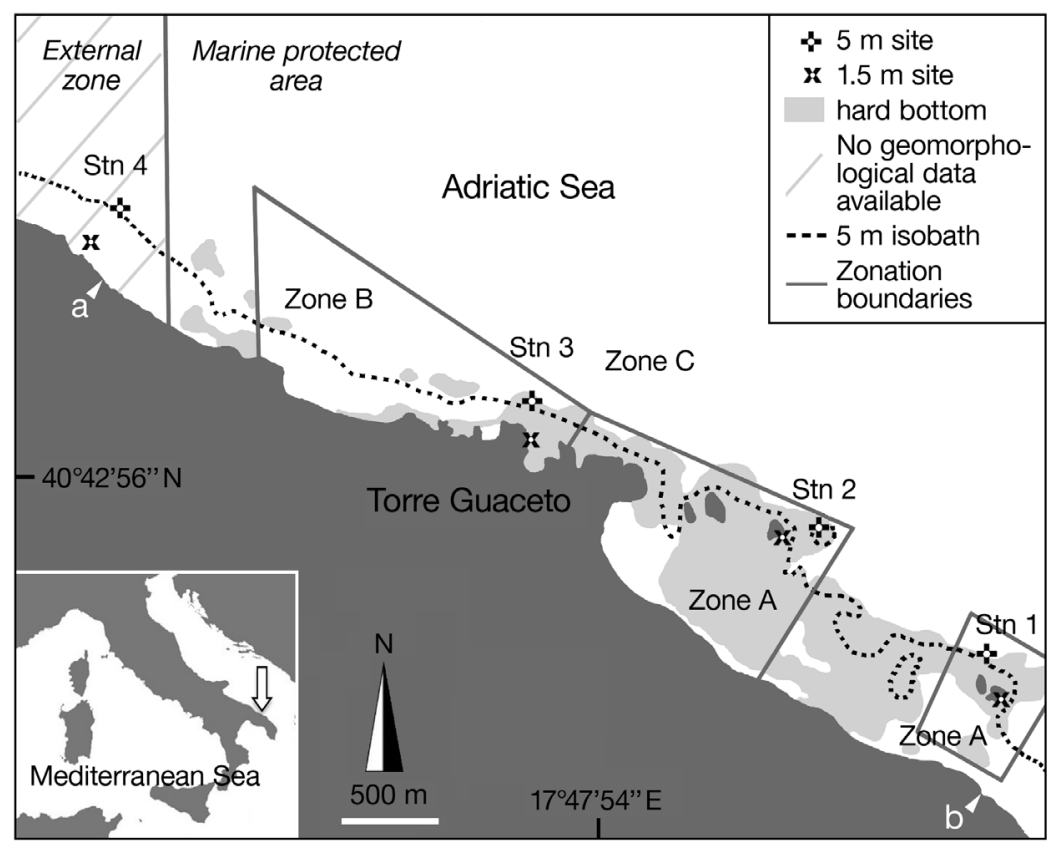

Fig. 1. Study area. Zones A, B, \& C represent decreasing levels of protection. Each of the 4 stations consists of a $1.5 \mathrm{~m}$ and a $5 \mathrm{~m}$ deep site. White arrowheads ' $a$ ' and ' $b$ ' are the reference points used to calculate the isolation level, see 'Materials and methods-Influence of protection and isolation on alongshore variation'. Geomorphological information is kindly provided by S. Fraschetti

declines with a gentle to medium slope from the water surface to a depth of $\sim 10 \mathrm{~m}$, over which coarse sand and sandy bottom alternate with hard bottom in a complex mosaic (Fig. 1). A detailed distribution map of the habitats in the MPA can be found in Fraschetti et al. (2005b).

Shallow algal assemblages in the area are dominated by turf-forming species such as Laurencia spp. and Corallina elongata; Ulva spp. is reported in the vicinity of the central peninsula, while canopy algae (Cystoseira spp.) are sparse. With increasing depth, Acetabularia acetabulum, Halimeda tuna, Padina pavonica, Dictyotales and Amphiroa rigida become dominant. Calcareous algae (such as Lithophyllum spp.) and the sponge Chondrilla nucula dominate sea-urchin barrens that occur sporadically in the area (Fraschetti et al. 2005b, A. Terlizzi pers. comm.). Tidal range is in the order of few centimetres; a NW wind is prevalent during a large part of the year.

Human activity has been regulated since 1991. In August 2006 the MPA was officially divided into A, B and $\mathrm{C}$ zones describing decreasing levels of protection, respectively (Fig. 1). This subdivision followed the Italian legislation and roughly correspond to the common subdivision of MPAs into 'no take zone' (Zone A) and 'buffer zone' (Zones B and C). However, pending a new regulation, the entire area will be a no-take zone. All human activities are banned from the A zone with the exclusion of scientific research; recreational activities are permitted in the remaining areas.

\section{Sampling method}

In August 2006, 4 sites at $5 \mathrm{~m}$ depth were randomly chosen 1000 to $2500 \mathrm{~m}$ apart, following the $5 \mathrm{~m}$ isobath and using the distribution map of hard bottom habitats provided elsewhere (Fraschetti et al. 2005b). Each $5 \mathrm{~m}$ site was paired with a similar site located at a depth of $1.5 \mathrm{~m}$, that was randomly chosen among available sites 150 to $300 \mathrm{~m}$ from the $5 \mathrm{~m}$ sites. Each pair of $1.5+5 \mathrm{~m}$ sites constituted 1 sampling station; there were 4 sampling stations in the study (Fig. 1).

Sampling was performed by SCUBA on 8 August 2006, by scraping off $10 \times 10 \mathrm{~cm}$ squares of hard substrate on vertical rocky walls all with a southeast orientation. The choice of the small sample size $\left(100 \mathrm{~cm}^{2}\right)$ was based on a pilot study of the polychaete distribution pattern in the south Adriatic area (Fraschetti et al. 2002) and aimed at minimizing impacts due to sampling in the MPA. At each site, 3 sampling units (replicates) were randomly chosen $\sim 1 \mathrm{~m}$ apart from each other and sampled using a hammer and a 'box-chisel' designed for the occasion

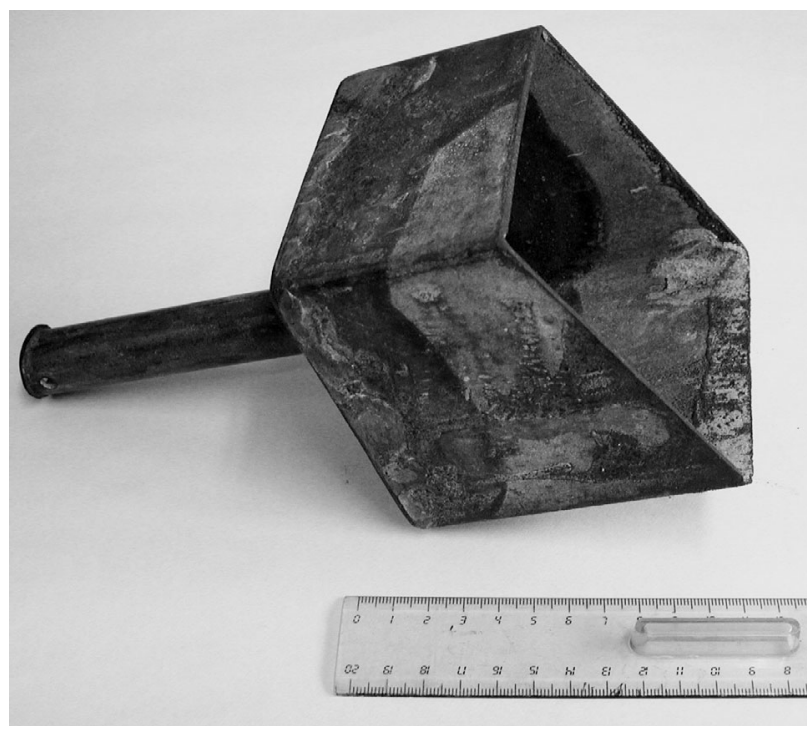

Fig. 2. Special box-chisel used for underwater sampling 
(Fig. 2). This newly designed device minimized the loss of organisms and associated sediment while scraping the substratum and proved a useful alternative to airlift sampling devices that may also damage the organisms (e.g. causing autotomy). Samples were carefully deposited into plastic bags and fixed with a $7 \%$ formalin seawater solution. At each site temperature and salinity were also measured.

In the laboratory the samples were washed in a $0.5 \mathrm{~mm}$ mesh sieve and transferred to $70 \%$ ethanol. The volume of sieved material associated with each of the samples was calculated $48 \mathrm{~h}$ after pouring the wash-water into $100 \mathrm{ml}$ graduated glass cylinders.

Sorting and counting were performed using a stereomicroscope. Among the sessile macrobenthos, the taxa considered as habitat formers for the Syllidae (hereafter termed the structuring macrobenthos) were identified (Riedl 1991) and weighed after drying $\left(60^{\circ} \mathrm{C}\right.$ for $\left.48 \mathrm{~h}\right)$. The polychaetes were identified to the Family level, while the other macrobenthic organisms were sorted at coarser taxonomic levels. The Syllidae were identified to species level in accordance with San Martín (2003), Licher (1999) and Nygren (2004) and deposited in the polychaete collection of the Laboratory of Marine Biology and Zoology at the University of Salento.

\section{Data analysis}

Two-way ANOVA was used to test differences in abundance and diversity of the Syllidae among sites and between the 2 depths. The model design consisted of 2 crossed factors: 'station' (4 levels, random) and 'depth' (2 levels, fixed) allowing the simultaneous analysis of the vertical and the horizontal patterns of assemblage distributions, and their interaction (station $\times$ depth). Horizontal patterns of variation in assemblages were further investigated by comparing the 4 sites separately for each depth.

The same analytical framework was used in the multivariate context to quantify differences in the structure of multivariate syllid assemblages by permutational multivariate analysis of variance (PERMANOVA), while 1-way PERMANOVA separately tested the null hypothesis of no differences among sites at each depth. Each term in the analysis was tested using 4999 random permutations of the appropriate units (Anderson \& ter Braak 2003).

The univariate and multivariate analyses were repeated by specifying protection rank as a covariate. Multivariate patterns of syllid assemblages were visualised by cluster analysis of the sites' centroids. A similarity percentage (SIMPER) routine was performed to detect the species responsible for dissimilarity among syllid assemblages.

In order to identify potentially important drivers of variation in syllid assemblages, non-parametric multiple regression analyses (McArdle \& Anderson 2001) were performed using the DISTLM-forward procedure (Distance-based multivariate analysis for a linear model using forward selection); covariates included temperature, salinity, depth, sediment volume, total dry weight and diversity (Simpson index) of the sessile macrobenthos (algae and sponges). The same abiotic covariables and the dry weight of each structuring macrobenthic taxon (cut-off $5 \%$ of the total dry weight) and the abundance of each macrofaunal taxon (cut-off $5 \%$ of the total abundance) were used in a second multiple regression analysis. The DISTLM-forward procedure also provided information on the correlation among all pairs of explanatory variables, allowing a further check on issues of multi-collinearity (Anderson 2003).

Analyses were performed using the computer program PRIMER v.6 including the add-on package PERMANOVA+ (Anderson et al. 2008).

\section{Influence of protection and isolation on alongshore variation}

Additional drivers of alongshore variation in syllid assemblages were among-site differences in the level of protection from anthropological disturbance (inside versus outside the MPA) and the degree of isolation (distance from the mainland). The 2 additional factors mostly overlapped, with Stn 1 and Stn 2 both being subjected to the same high levels of protection and isolation, Stn 3 being exposed to intermediate levels of both factors (but see below, this paragraph) and Stn 4 having the lowest levels of protection and separation from the mainland (Fig. 1). To control for these effects, the analyses were repeated with level of protection and degree of isolation as covariables. Level of protection from anthropological disturbance was coded by assigning 0 to fully-accessible sites outside the MPA, 1 to fully protected sites within Zone $\mathrm{A}$, and the intermediate values of 0.33 and 0.66 to sites within Zones $\mathrm{C}$ and $\mathrm{B}$, respectively. However, within Zones B and C, only the shallowest areas were expected to experience some form of human disturbance (where only bathing was allowed), whereas the conditions at $5 \mathrm{~m}$ depth (some 100s of metres from the coastline, see Fig. 1) could reason- 

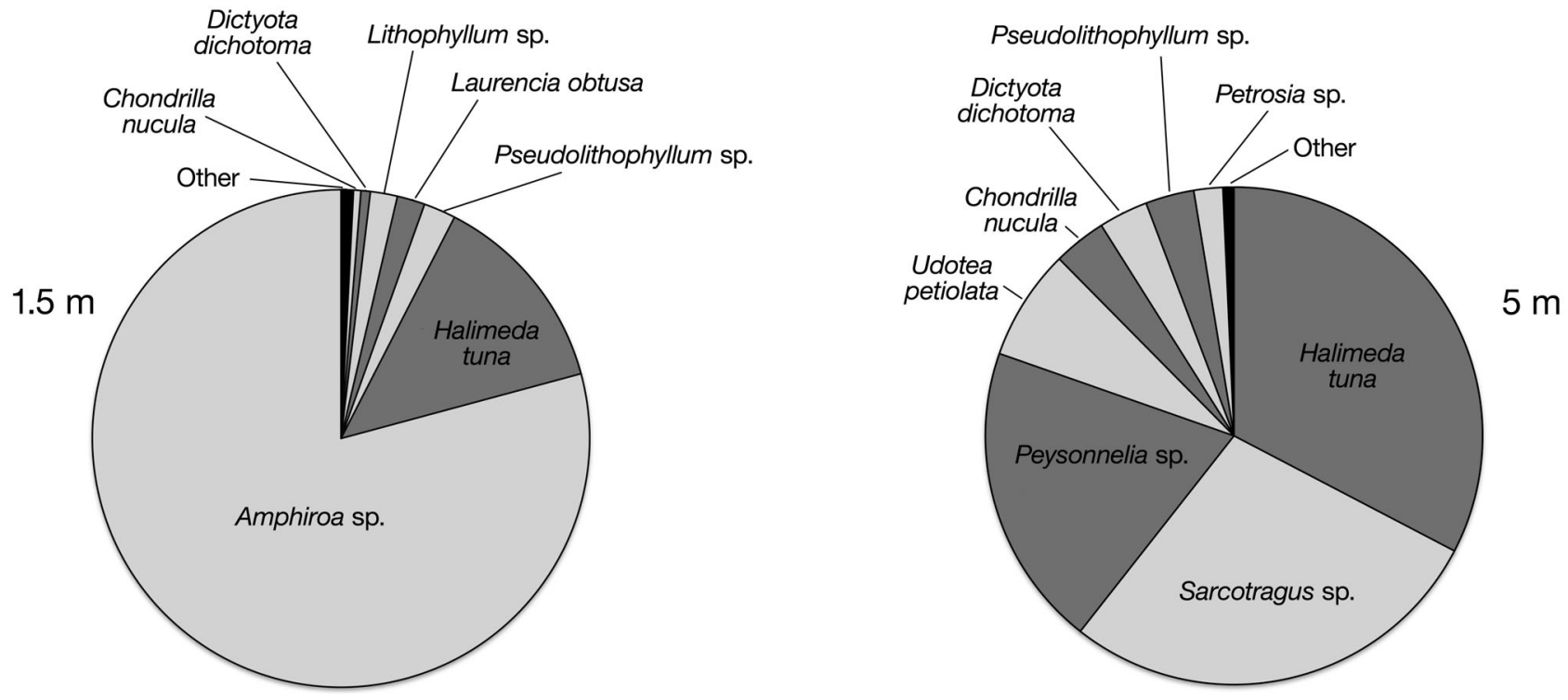

Fig. 3. Proportions of the structuring macrobenthic species in the samples collected at 1.5 and $5 \mathrm{~m}$ depths. Total dry weight $($ dry wt $)=137.25 \mathrm{~g}(1.5 \mathrm{~m})$ and $57.34 \mathrm{~g}(5 \mathrm{~m})$, and average dry wt $( \pm \mathrm{SE}, \mathrm{n}=12)=11.44 \pm 1.30 \mathrm{~g}(1.5 \mathrm{~m})$ and $4.78 \pm 0.67 \mathrm{~g}(5 \mathrm{~m})$
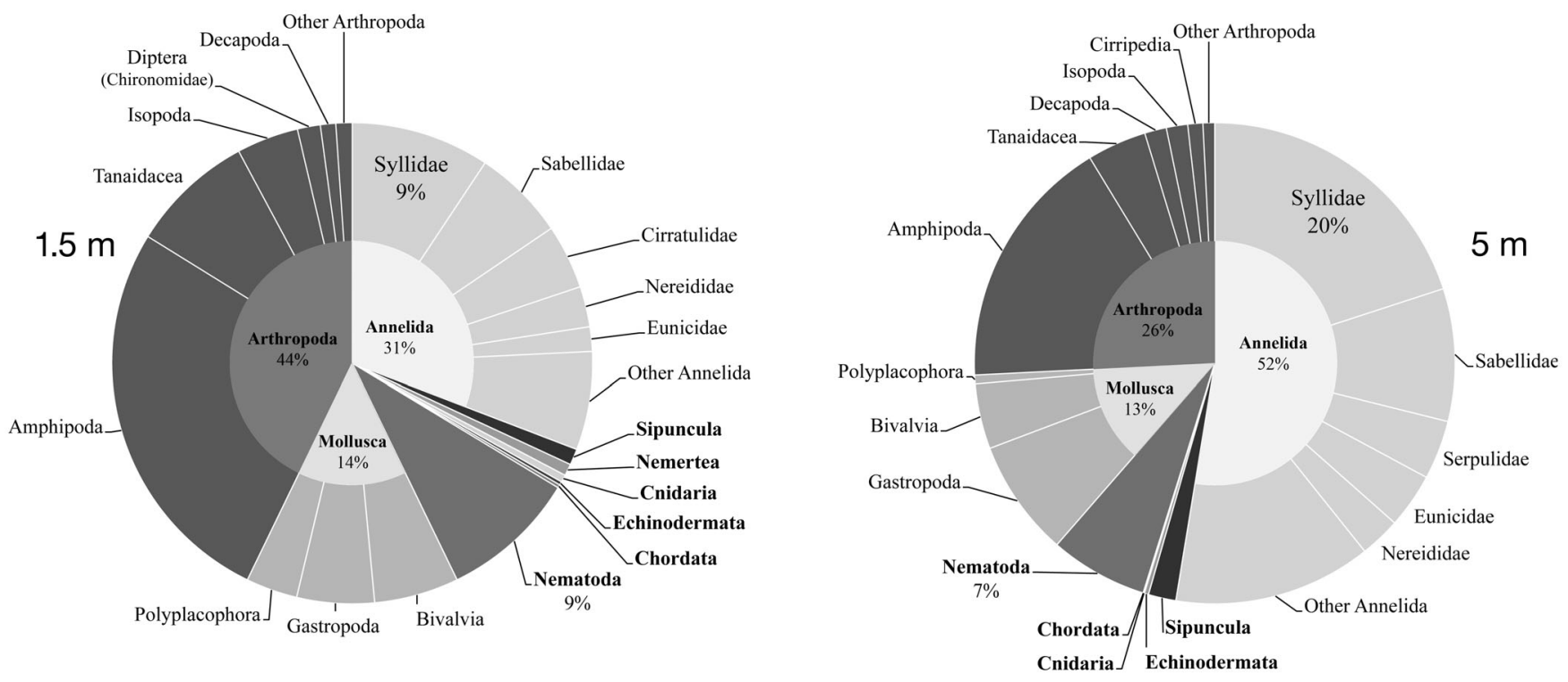

Fig. 4. Abundances of the Syllidae species with respect to the other macrofaunal taxa at 1.5 and $5 \mathrm{~m}$ depths

ably be considered similar to those occurring in the MPA. As a consequence, the $5 \mathrm{~m}$ site at Stn 3 was scored as fully protected. The degree of isolation was assessed using the distance between a given sampling station and the virtual line passing from the 2 coastal points having the same longitude of the northern-most and southern-most stations (Stns 4 and 1 respectively, see Fig. 1) as a proxy. Protection and isolation, as expected, were highly collinear so only protection was used as a covariable in the analysis.

\section{RESULTS}

\section{Descriptive analysis}

The algae Amphiroa sp. and Halimeda tuna dominated macrobenthic assemblages at $1.5 \mathrm{~m}$ depth; the latter alga was also abundant at $5 \mathrm{~m}$ depth, together with the sponges Petrosia sp., Chondrilla nucula and Sarcotragus sp. (Fig. 3).

Specimens of Arthropoda and Polychaeta were abundant at both depths, the first contributing $44 \%$ of the 
Table 1. List of Syllidae species and their total abundances at 1.5 and $5 \mathrm{~m}$ depths around the Torre Guaceto marine protected area (SE Italy)

\begin{tabular}{|c|c|c|}
\hline \multirow[t]{2}{*}{ Taxon } & \multicolumn{2}{|c|}{ —Abundance (n) - } \\
\hline & $1.5 \mathrm{~m}$ & $5 \mathrm{~m}$ \\
\hline Branchiosyllis exilis & 1 & 1 \\
\hline Brania arminii & 1 & 0 \\
\hline B. pusilla & 8 & 17 \\
\hline Erinaceusyllis belizensis ${ }^{\mathrm{a}}$ & 1 & 5 \\
\hline E. serratosetosa ${ }^{\mathrm{a}}$ & 5 & 0 \\
\hline Eurysyllis tuberculata & 1 & 1 \\
\hline Eusyllis lamelligera & 1 & 5 \\
\hline Exogone (Exogone) dispar & 11 & 51 \\
\hline E. (Exogone) naidina & 204 & 100 \\
\hline E. (Exogone) rostrata & 0 & 14 \\
\hline Haplosyllis spongicola & 16 & 18 \\
\hline Myrianida brachycephala & 0 & 1 \\
\hline M. convoluta & 0 & 1 \\
\hline M. edwardsi & 1 & 0 \\
\hline Myrianida sp. & 0 & 3 \\
\hline Nudisyllis pulligera ${ }^{\mathrm{C}}$ & 17 & 2 \\
\hline Odontosyllis ctenostoma & 0 & 20 \\
\hline O. fulgurans & 0 & 2 \\
\hline Paraehlersia ferrugina & 17 & 6 \\
\hline Parapionosyllis brevicirra & 1 & 1 \\
\hline Pionosyllis lamelligera & 20 & 36 \\
\hline Proceraea aurantiaca & 3 & 0 \\
\hline Prosphaerosyllis campoyi ${ }^{\mathrm{b}}$ & 0 & 1 \\
\hline Prosphaerosyllis sp. & 1 & 0 \\
\hline Salvatoria clavata & 43 & 68 \\
\hline S. euritmica ${ }^{\mathrm{b}}$ & 0 & 13 \\
\hline S. limbata & 9 & 5 \\
\hline Salvatoria sp. & 1 & 1 \\
\hline Sphaerosyllis boeroi ${ }^{\mathrm{b}}$ & 5 & 38 \\
\hline S. hystrix & 0 & 20 \\
\hline S. pirifera & 5 & 19 \\
\hline S. taylori & 2 & 0 \\
\hline Syllides fulvus & 0 & 1 \\
\hline Syllis gerundensis & 0 & 1 \\
\hline S. armillaris & 9 & 24 \\
\hline S. beneliahuae & 16 & 6 \\
\hline S. cf. armillaris & 2 & 0 \\
\hline S. corallicola & 4 & 25 \\
\hline S. ferrani & 1 & 17 \\
\hline S. garciai & 3 & 5 \\
\hline S. gerlachi & 112 & 93 \\
\hline S. gracilis & 5 & 0 \\
\hline S. hyalina & 0 & 1 \\
\hline S. krohni & 1 & 4 \\
\hline S. prolifera & 25 & 40 \\
\hline S. pulvinata & 0 & 1 \\
\hline S. variegata & 3 & 29 \\
\hline Syllis sp. & 3 & 0 \\
\hline Trypanosyllis coeliaca & 5 & 7 \\
\hline T. zebra & 3 & 3 \\
\hline $\begin{array}{l}{ }^{a} \text { New to the Italian coast }{ }_{i}{ }^{b} \\
{ }^{c} \text { new to the South Adriatic }\end{array}$ & he Adri & Sea; \\
\hline
\end{tabular}

6028 ind. collected at $1.5 \mathrm{~m}$ and the latter representing $52 \%$ of the 3552 ind. collected at $5 \mathrm{~m}$ (Fig. 4).

Syllidae was the dominant polychaete family at both depths (Fig. 4), with 562 and 710 ind. collected at 1.5 and $5 \mathrm{~m}$, respectively, and an average density of $5300 \pm 741.58$ ind. $\mathrm{m}^{-2}( \pm \mathrm{SE} ; \mathrm{n}=24)$. Among the 50 syllid species identified, 35 were recorded at $1.5 \mathrm{~m}$ and 43 at $5 \mathrm{~m}$. Exogone naidina, Syllis gerlachi and Salvatoria clavata were the most abundant species at both depths. The percentage of singleton species (represented by only 1 ind. in each sample) was about $28 \%$ at both depths. About 70 and $58 \%$ of the species occurred with $<10$ ind. per sample at 1.5 and $5 \mathrm{~m}$, respectively. Several species were new biogeographic records (Table 1).

\section{Univariate tests}

The 2-way ANOVA testing for differences in the syllid abundance did not reveal any significant dif-

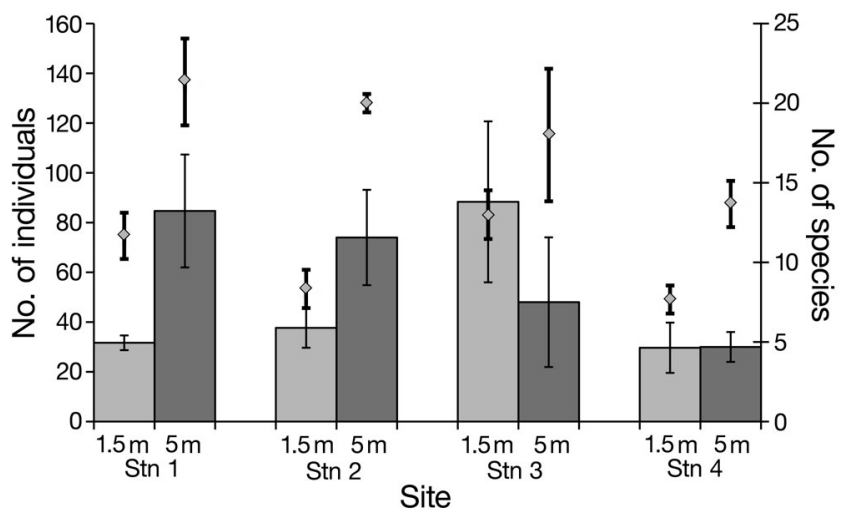

Fig. 5. Average syllid abundance (bars, $\pm \mathrm{SE}, \mathrm{n}=3$ ) and species number (diamonds, $\pm \mathrm{SE}, \mathrm{n}=3$ ) per site at $1.5 \mathrm{~m}$ (light grey) and $5 \mathrm{~m}$ (dark grey) depths

Table 2. 2-way ANOVA testing for differences in abundance (no. of individuals) and diversity (no. of species) of the Syllidae. st $=$ station, de $=$ depth, res: residual, $F_{v s}=$ denominator used in the $F$-ratio; significant $\mathrm{p}$-values $(\mathrm{p}<0.05)$ are given in bold

\begin{tabular}{|lrcccl|}
\hline Factor & df & MS & $F$ & $p$ & $F_{\text {vs }}$ \\
\hline Abundance & & & & & \\
st & 3 & 1602.9 & 1.5162 & 0.247 & res \\
de & 1 & 912.67 & 0.3546 & 0.610 & de $\times$ st \\
de $\times$ st & 3 & 2573.8 & 2.4345 & 0.098 & res \\
res & 16 & 1057.2 & & & \\
Diversity & & & & & \\
st & 3 & 38.931 & 3.0634 & 0.060 & res \\
de & 1 & 392.04 & 26.857 & $\mathbf{0 . 0 3 3}$ & de $\times$ st \\
de $\times$ st & 3 & 14.597 & 1.1486 & 0.350 & res \\
res & 16 & 12.708 & & & \\
\hline
\end{tabular}


Table 3. 2-way PERMANOVA testing for differences in the multivariate syllid assemblages. Untransformed data and presence/absence data transformed. st $=$ station, de $=$ depth, res: residual, $F_{\mathrm{vs}}=$ denominator used in the $F$-ratio. Significant $p$-values $(p<0.05)$ are given in bold

\begin{tabular}{|lrcccl|}
\hline Factor & df & MS & $F$ & $\mathrm{p}$ & \multicolumn{1}{c|}{$F_{\text {vs }}$} \\
\hline Untransformed & & & & & \\
st & 3 & 2565.9 & 1.8514 & $\mathbf{0 . 0 0 7 4}$ & res \\
de & 1 & 7408.5 & 2.1586 & 0.0842 & de $\times$ st \\
de $\times$ st & 3 & 3432.1 & 2.4764 & $\mathbf{0 . 0 0 1 8}$ & res \\
res & 16 & 1385.9 & & & \\
Transformed & & & & & \\
st & 3 & 1226.2 & 1.5721 & 0.0736 & res \\
de & 1 & 8361.1 & 4.3598 & $\mathbf{0 . 0 1 5}$ & de $\times$ st \\
de $\times$ st & 3 & 1917.8 & 2.4588 & $\mathbf{0 . 0 0 0 4}$ & res \\
res & 16 & 779.98 & & & \\
\hline
\end{tabular}

ferences among stations or between depths (Fig. 5, Table 2a). Repeating the analysis with protection level as a covariable resulted in the same pattern of significance (mean square [MS] of station $\times$ depth $=$ 1086.9, $F_{2,16}=1.03, \mathrm{p}=0.38 ; \mathrm{MS}$ of station $=1593.3$, $F_{3,16}=1.51, \mathrm{p}=0.25 ; \mathrm{MS}$ of depth $=4020.1, F_{1,3}=3.70$ ， $\mathrm{p}=0.19]$.

Testing for differences in the number of syllid species revealed significant differences between depths but not among stations (Fig. 5, Table 2b). Repeating the analysis with protection level as a covariable resulted in the same pattern in terms of significance $\left(\mathrm{MS}\right.$ of station $\times$ depth $=12.4, F_{2,16}=0.97, \mathrm{p}=0.39$; MS of station $=12.2, F_{3,16}=0.96, p=0.43 ; \mathrm{MS}$ of depth $=373.6, F_{1,3}=30.15, \mathrm{p}=0.035$ ).

\section{Multivariate tests}

The results of the PERMANOVAs examining multivariate variation in syllid assemblages revealed a significant station $\times$ depth interaction in both the abundance (Table 3 ) and presence/absence (Table 3b) data, indicating that the pattern of alongshore variation changed with depth. Repeating the analysis with protection level as a covariate did not change the results in both cases (analysis with original abundance data: $\mathrm{MS}$ of station $\times$ depth $=2924.9, F_{2,16}=$ $2.11, \mathrm{p}=0.0046$; analysis with presence/absence transformed data: MS of station $\times$ depth $=1883.5$, $F_{2,16}=2.41, \mathrm{p}=0.0036$ ).

Separate PERMANOVAs run by depth revealed significant alongshore variation among assemblages at 1.5 , but not at $5 \mathrm{~m}$ depth (Table 4 ). Repeating the analysis with protection level as a covariable gener-
Table 4. 1-way PERMANOVA separately testing differences in the syllid multivariate assemblages among sites at $1.5 \mathrm{~m}$ and among sites at $5 \mathrm{~m}$ depths. Untransformed data and presence/absence data transformed. $F_{\mathrm{vs}}=$ denominator used in the $F$-ratio; significant $\mathrm{p}$-values $(\mathrm{p}<0.05)$ are given in bold

\begin{tabular}{|lcccccc|}
\hline Depth & Factor & df & MS & $F$ & $\mathrm{p}$ & $F_{\mathrm{vs}}$ \\
\hline \multicolumn{2}{l}{ Untransformed } \\
$1.5 \mathrm{~m}$ & site & 3 & 3569.5 & 2.6044 & $\mathbf{0 . 0 0 7 6}$ & res \\
& res & 8 & 1370.5 & & & \\
$5 \mathrm{~m}$ & site & 3 & 2428.6 & 1.733 & 0.0838 & res \\
& res & 8 & 1401.3 & & & \\
\multicolumn{7}{l}{ Transformed } \\
$1.5 \mathrm{~m}$ & site & 3 & 2338.9 & 2.5417 & $\mathbf{0 . 0 1 4 4}$ & res \\
$5 \mathrm{~m}$ & res & 8 & 920.2 & & & \\
& site & 3 & 805.13 & 1.2585 & 0.2534 & res \\
& res & 8 & 639.76 & & & \\
\hline
\end{tabular}

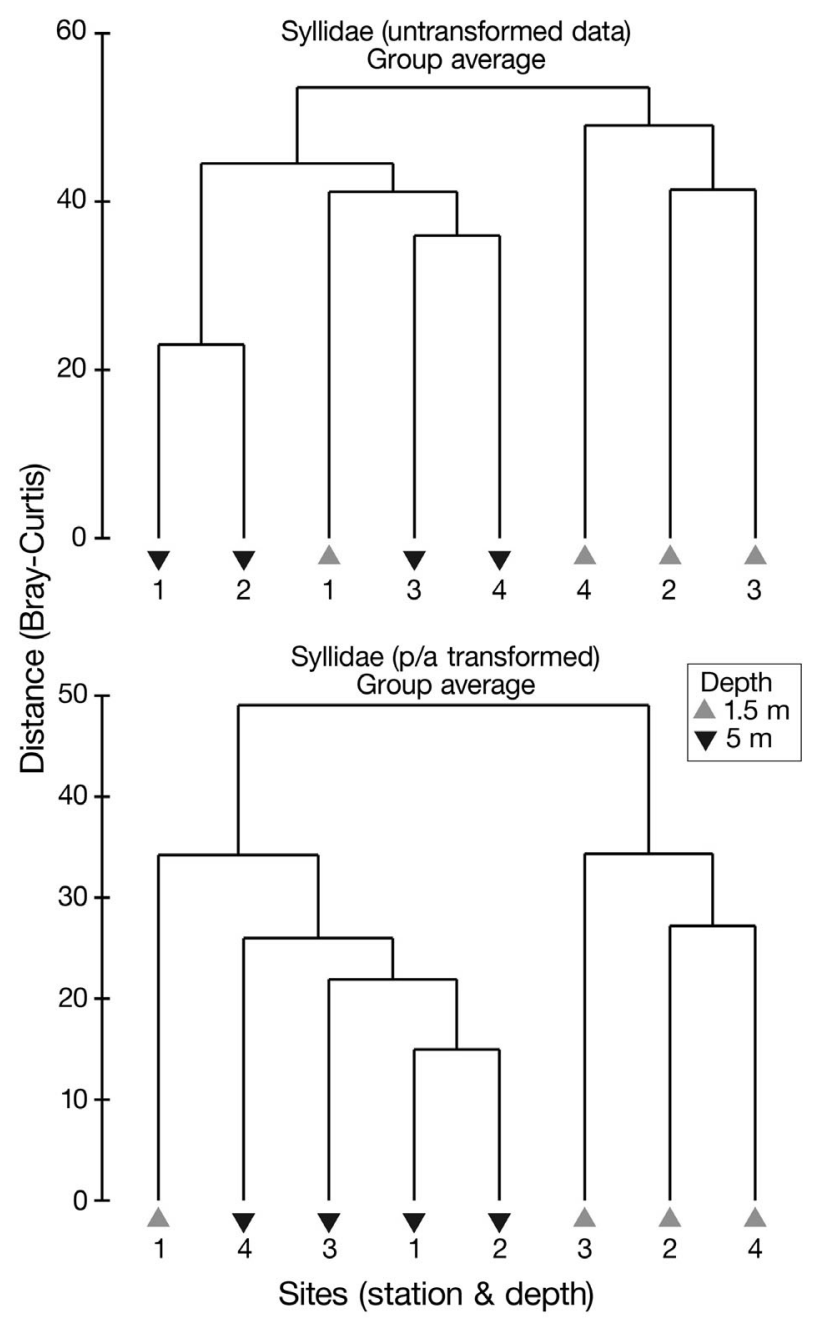

Fig. 6. Cluster analysis (Bray-Curtis) of the multivariate syllid assemblages based on the site centroids calculated from the original data and after presence/absence transformation 
ated similar results $(1.5 \mathrm{~m}$ sites: $\mathrm{MS}$ of site $=3487.3$, $F_{2,8}=2.54, \mathrm{p}=0.02 ; 5 \mathrm{~m}$ sites: $\mathrm{MS}$ of site $=1935.7, F_{2,8}$ $=1.38, \mathrm{p}=0.21$ ).

Similar results were obtained using presence/absence data (Table 4); significant differences among stations were observed at 1.5 , but not at $5 \mathrm{~m}$ depth. Repeating the analysis with protection level as a covariable did not change the results $(1.5 \mathrm{~m}$ sites: MS of site $=2229.6, F_{2,8}=2.42, \mathrm{p}=0.028 ; 5 \mathrm{~m}$ sites: $\mathrm{MS}$ of site $=590.9, F_{2,8}=0.92, \mathrm{p}=0.52$ ). These patterns are well visualized by the cluster analysis (Fig. 6).

\section{SIMPER analysis}

SIMPER analysis (Table 5) indicated that site-tosite dissimilarity at $1.5 \mathrm{~m}$ depth was generally due to the dominance of few syllid species, mostly Exogone naidina and Syllis gerlachi, while a larger number of species contributed to site-to-site dissimilarity at $5 \mathrm{~m}$ depth. Differences in taxonomic composition (i.e. species presence/absence) were more influential in differentiating sites at $1.5 \mathrm{~m}$ than at $5 \mathrm{~m}$. In general, the dissimilarity between syllid assemblages at $1.5 \mathrm{~m}$

Table 5 (continued on next page). SIMPER analysis: syllid species responsible for site-to-site dissimilarity at 1.5 and $5 \mathrm{~m}$ depth. Cut off for low contributions: $70 \%$. Av.D. = average dissimilarity $(\%) ;$ Av.A. = average abundance; $\mathrm{C} \%=$ percent contribution. Full species names in Table 1

\begin{tabular}{|c|c|c|c|c|c|c|c|c|}
\hline \multirow{3}{*}{$\begin{array}{l}\text { Station } \\
1 \& 2\end{array}$} & \multirow{3}{*}{$\begin{array}{l}\text { Species } \\
\text { Av.D. }=58.11\end{array}$} & \multirow{2}{*}{\multicolumn{2}{|c|}{$5 \mathrm{~m}-\mathrm{Av} \cdot \mathrm{A}}}$. & \multirow{3}{*}{$\mathrm{C} \%$} & \multirow{3}{*}{$\begin{array}{l}\text { Species } \\
\text { Av.D. }=47.01\end{array}$} & \multirow{2}{*}{\multicolumn{2}{|c|}{$\mathrm{m}-\mathrm{Av} \cdot \mathrm{A} . \longrightarrow$}} & \multirow{3}{*}{$\mathrm{C} \%$} \\
\hline & & & & & & & & \\
\hline & & Stn 1 & Stn 2 & & & Stn 1 & Stn 2 & \\
\hline & S. gerlachi & 5.33 & 11 & 14.46 & E. naidina & 17.33 & 13.67 & 17.62 \\
\hline & E. naidina & 5.33 & 10.33 & 13.12 & S. clavata & 8 & 7 & 7.62 \\
\hline & H. spongicola & 3.33 & 1.33 & 10.06 & P. lamelligera & 7 & 2.67 & 7.13 \\
\hline & S. prolifera & 3.67 & & 8.94 & E. dispar & 6.67 & 5.67 & 6.29 \\
\hline & S. clavata & 1.67 & 4.33 & 7.68 & S. euritmica & 3.33 & & 5.08 \\
\hline & N. pulligera & & 2 & 4.72 & S. gerlachi & 9 & 8.67 & 4.64 \\
\hline & P. lamelligera & 0.67 & 2.67 & 4.65 & H. spongicola & 4 & 1 & 4.41 \\
\hline & S. armillaris & 2.33 & 0.67 & 4.19 & O. cf ctenostoma & 3.67 & 0.67 & 4.4 \\
\hline & S. gracilis & 1.67 & & 4.16 & S. boeroi & 2 & 5 & 3.88 \\
\hline & & & & & S. prolifera & 2 & 3.33 & 3.67 \\
\hline & & & & & S. variegata & 4.33 & 3.67 & 3.53 \\
\hline & & & & & E. rostrata & 0.67 & 2.67 & 3.44 \\
\hline \multirow[t]{12}{*}{$1 \& 3$} & Av.D. $=71.54$ & Stn 1 & Stn 3 & & Av.D. $=64.41$ & Stn 1 & Stn 3 & \\
\hline & E. naidina & 5.33 & 42 & 39.3 & E. naidina & 17.33 & 1.67 & 18.41 \\
\hline & S. gerlachi & 5.33 & 17.67 & 12.26 & S. gerlachi & 9 & 9 & 10.03 \\
\hline & S. prolifera & 3.67 & 3.33 & 6.05 & E. dispar & 6.67 & 3.67 & 7.19 \\
\hline & H. spongicola & 3.33 & 0.67 & 4.89 & S. clavata & 8 & 2 & 7.01 \\
\hline & S. clavata & 1.67 & 4.33 & 4.05 & P. lamelligera & 7 & 1 & 6.57 \\
\hline & S. armillaris & 2.33 & & 3.11 & S. variegata & 4.33 & 1.33 & 4.46 \\
\hline & P. lamelligera & 0.67 & 3.33 & 3.09 & S. euritmica & 3.33 & 1 & 4.29 \\
\hline & & & & & S. hystrix & 1.33 & 3.67 & 3.86 \\
\hline & & & & & O. cf. ctenostoma & 3.67 & 1.33 & 3.85 \\
\hline & & & & & H. spongicola & 4 & 0.67 & 3.65 \\
\hline & & & & & S. prolifera & 2 & 3.67 & 3.49 \\
\hline \multirow[t]{11}{*}{$1 \& 4$} & Av.D. $=69.71$ & Stn 1 & Stn 4 & & Av.D. $=65.60$ & Stn 1 & Stn 4 & \\
\hline & E. naidina & 5.33 & 10.33 & 17.16 & E. naidina & 17.33 & 0.67 & 20.69 \\
\hline & P. ferrugina & & 5 & 12.64 & E. dispar & 6.67 & 1 & 8.13 \\
\hline & H. spongicola & 3.33 & & 9.22 & P. lamelligera & 7 & 1.33 & 7.31 \\
\hline & S. gerlachi & 5.33 & 3.33 & 8.29 & S. gerlachi & 9 & 4.33 & 5.88 \\
\hline & S. prolifera & 3.67 & 1.33 & 7.79 & S. clavata & 8 & 5.67 & 5.45 \\
\hline & S. clavata & 1.67 & 4 & 6.95 & S. variegata & 4.33 & 0.33 & 5.43 \\
\hline & S. armillaris & 2.33 & & 5.8 & S. euritmica & 3.33 & & 5.15 \\
\hline & N. pulligera & & 2.33 & 5.12 & S. prolifera & 2 & 4.33 & 4.62 \\
\hline & & & & & O. cf. ctenostoma & 3.67 & 1 & 4.12 \\
\hline & & & & & H. spongicola & 4 & 0.33 & 3.95 \\
\hline
\end{tabular}


Table 5 (continued)

\begin{tabular}{|c|c|c|c|c|c|c|c|c|}
\hline \multirow{3}{*}{$\begin{array}{l}\text { Station } \\
2 \& 3\end{array}$} & \multirow{3}{*}{$\begin{array}{l}\text { Species } \\
\text { Av.D. }=55.55\end{array}$} & \multirow{2}{*}{\multicolumn{2}{|c|}{$.5 \mathrm{~m}-\mathrm{Av} \cdot \mathrm{A}}}$. & \multirow{3}{*}{$\mathrm{C} \%$} & \multirow{3}{*}{$\begin{array}{l}\text { Species } \\
\text { Av.D. }=58.14\end{array}$} & \multirow{2}{*}{\multicolumn{2}{|c|}{$\mathrm{m}-\mathrm{Av} \cdot \mathrm{A}}}$. & \multirow{3}{*}{$\mathrm{C} \%$} \\
\hline & & & & & & & & \\
\hline & & $\operatorname{Stn} 2$ & Stn 3 & & & Stn 2 & Stn 3 & \\
\hline & E. naidina & 10.33 & 42 & 40.99 & E. naidina & 13.67 & 1.67 & 15.73 \\
\hline & S. gerlachi & 11 & 17.67 & 11.39 & S. gerlachi & 8.67 & 9 & 11.61 \\
\hline & S. clavata & 4.33 & 4.33 & 6.04 & S. clavata & 7 & 2 & 7.78 \\
\hline & S. prolifera & & 3.33 & 5.58 & E. dispar & 5.67 & 3.67 & 6.88 \\
\hline & P. lamelligera & 2.67 & 3.33 & 4.2 & S. pirifera & 4 & & 5.57 \\
\hline & S. limbata & & 2.67 & 3.67 & S. variegata & 3.67 & 1.33 & 4.69 \\
\hline & & & & & S. boeroi & 5 & 4.33 & 4.68 \\
\hline & & & & & E. rostrata & 2.67 & 1.33 & 3.85 \\
\hline & & & & & S. corallicola & 2.33 & 3.33 & 3.64 \\
\hline & & & & & P. lamelligera & 2.67 & 1 & 3.51 \\
\hline & & & & & S. hystrix & 1 & 3.67 & 3.46 \\
\hline \multirow[t]{11}{*}{$2 \& 4$} & Av.D. $=58.26$ & Stn 2 & Stn 4 & & Av.D. $=56.08$ & Stn 2 & Stn 4 & \\
\hline & E. naidina & 10.33 & 10.33 & 24.39 & E. naidina & 13.67 & 0.67 & 18.42 \\
\hline & S. gerlachi & 11 & 3.33 & 22.01 & E. dispar & 5.67 & 1 & 8.24 \\
\hline & P. ferrugina & 0.33 & 5 & 12.91 & S. gerlachi & 8.67 & 4.33 & 6.7 \\
\hline & P. lamelligera & 2.67 & & 6.73 & S. clavata & 7 & 5.67 & 6.69 \\
\hline & S. clavata & 4.33 & 4 & 6.26 & S. variegata & 3.67 & 0.33 & 6.3 \\
\hline & & & & & S. pirifera & 4 & & 6.29 \\
\hline & & & & & S. boeroi & 5 & 1.33 & 6.05 \\
\hline & & & & & E. rostrata & 2.67 & & 4.45 \\
\hline & & & & & P. lamelligera & 2.67 & 1.33 & 3.82 \\
\hline & & & & & S. corallicola & 2.33 & 0.33 & 3.38 \\
\hline \multirow[t]{12}{*}{$3 \& 4$} & Av.D. $=66.82$ & Stn 3 & Stn 4 & & Av.D. $=56.78$ & Stn 3 & Stn 4 & \\
\hline & E. naidina & 42 & 10.33 & 38.25 & S. gerlachi & 9 & 4.33 & 13.04 \\
\hline & S. gerlachi & 17.67 & 3.33 & 16.42 & S. clavata & 2 & 5.67 & 11.11 \\
\hline & $P$. ferrugina & 0.33 & 5 & 6.85 & S. corallicola & 3.33 & 0.33 & 8.03 \\
\hline & S. prolifera & 3.33 & 1.33 & 5.68 & S. hystrix & 3.67 & 0.67 & 6.21 \\
\hline & S. clavatta & 4.33 & 4 & 5.47 & S. prolifera & 3.67 & 4.33 & 6.14 \\
\hline & & & & & E. dispar & 3.67 & 1 & 5.95 \\
\hline & & & & & S. boeroi & 4.33 & 1.33 & 5.93 \\
\hline & & & & & B. pusilla & 1.67 & 1.67 & 4.3 \\
\hline & & & & & O. cf. ctenostoma & 1.33 & 1 & 3.7 \\
\hline & & & & & S. armillaris & 2.33 & 2.33 & 3.31 \\
\hline & & & & & S. variegata & 1.33 & 0.33 & 3.21 \\
\hline
\end{tabular}

and $5 \mathrm{~m}$ (average dissimilarity of $67 \%$ ) was mainly due to differences in abundance of species that occurred at both depths (i.e. E. naidina, S. gerlachi, Salvatoria clavata and Syllis prolifera).

\section{DISTLM-forward analysis}

Table 6 reports the results of the nonparametric multiple regression analysis (DISTLM-forward analysis). The conditional test (i.e. fitting each variable one at a time, conditional on the variables that are already included in the model) selected 7 variables (over a total of 41) that significantly explained 60.1\% of syllid assemblage variation. Depth was the most important predictor variable explaining $15.6 \%$ of syllid assemblage variation. The contribution of protection was low but significant (Table 6). Sediment volume contributed almost no variation and was dropped from the model, whereas salinity and temperature were excluded due to collinearity with depth. Among the macroalgal taxa, only Dictyota dichotoma (5.7\%) and Halimeda tuna (4.6\%) were significantly related to syllid assemblage distribution. Among the macrofaunal taxa Sabellidae (5\%), Decapoda (9.1\%) and Eunicidae (14.3\%) explained a large amount of variation in syllid assemblages. The additional analysis testing 2 synthetic predictors of 
Table 6. DISTLM-forward analysis. Multivariate multiple regression based on Bray-Curtis dissimilarities with a forward selection of the predictor variables of the syllid assemblage distributions in a linear regression model with tests by permutation (4999). Results of the forward selection procedure with the conditional tests (i.e. fitting each variable one at a time, conditional on the variables that are already included in the model). Significant $p$-values are given in bold. Underlined: significant proportion of explained variation (prop.); cumulative: cumulative proportion of explained variation

\begin{tabular}{|lrrrrr|}
\hline Variable & SS(Trace) & Pseudo- $F$ & $\mathrm{p}$ & $\begin{array}{c}\text { Prop. } \\
\text { of var. }\end{array}$ & $\begin{array}{c}\text { Cumula- } \\
\text { tive }\end{array}$ \\
\hline Depth & 7408.5415 & 4.0576 & $\mathbf{0 . 0 0 0 8}$ & $\underline{0.1557}$ & 0.1557 \\
Eunicidae & 6796.9978 & 4.2771 & $\mathbf{0 . 0 0 0 2}$ & $\underline{0.1429}$ & 0.2986 \\
Decapoda & 4333.7444 & 2.9849 & $\mathbf{0 . 0 0 1 2}$ & $\underline{0.0911}$ & 0.3897 \\
Protection rank & 3046.2583 & 2.2268 & $\mathbf{0 . 0 0 9 0}$ & $\underline{0.0640}$ & 0.4537 \\
D. dichotoma & 2737.6430 & 2.1191 & $\mathbf{0 . 0 1 3 8}$ & $\underline{0.0575}$ & 0.5112 \\
Sabellidae & 2379.3170 & 1.9376 & $\mathbf{0 . 0 3 2 4}$ & $\underline{0.0500}$ & 0.5612 \\
H. tuna & 2196.7033 & 1.8817 & $\mathbf{0 . 0 3 9 4}$ & $\underline{0.0462}$ & $\underline{0.6074}$ \\
Cirratulidae & 1984.9814 & 1.7836 & 0.0522 & 0.0417 & 0.6491 \\
C. nucula & 1648.7832 & 1.5343 & 0.1172 & 0.0347 & 0.6838 \\
Terebellidae & 1631.0166 & 1.5807 & 0.1172 & 0.0343 & 0.7181 \\
Amphipoda & 1647.2031 & 1.6799 & 0.1000 & 0.0346 & 0.7527 \\
Isopoda & 1213.8746 & 1.2654 & 0.2616 & 0.0255 & 0.7782 \\
Prosobranchia & 1251.3205 & 1.3453 & 0.2326 & 0.0263 & 0.8045 \\
Vermicularidae & 1276.7662 & 1.4320 & 0.2038 & 0.0268 & 0.8313 \\
L. obtusa & 1120.0152 & 1.2977 & 0.2764 & 0.0235 & 0.8549 \\
Spionidae & 1211.7668 & 1.4901 & 0.2024 & 0.0255 & 0.8804 \\
Sabellaridae & 1065.1971 & 1.3812 & 0.2508 & 0.0224 & 0.9027 \\
Serpulidae & 1152.3841 & 1.6581 & 0.1954 & 0.0242 & 0.9270 \\
Chironomida & 953.0856 & 1.5117 & 0.2490 & 0.0200 & 0.9470 \\
Petrosia sp. & 929.4728 & 1.7510 & 0.2328 & 0.0195 & 0.9665 \\
Sipuncula & 759.9796 & 1.8258 & 0.2712 & 0.0160 & 0.9825 \\
Polyplacophora & 793.5682 & 20.393 & 0.1018 & 0.0167 & 0.9992 \\
Opheliidae & 38.9130 & 0.0000 & 0.9998 & 0.0008 & 1.0000 \\
\hline
\end{tabular}

the structure of macrobenthos (total dry weight and Simpson index) indicated that the contribution of macrobenthic biomass (pseudo- $F=1.1, \mathrm{p}=0.3$, proportion of explained variation [prop.] $=0.04$ ) and diversity (pseudo- $F=0.9, \mathrm{p}=0.47$, prop. $=0.04$ ) were negligible and not significant. The univariate linear regression between macrobenthos biomass and Syllidae abundance also revealed weak correlation $\left(\mathrm{R}^{2}=0.0031\right)$.

\section{DISCUSSION}

\section{Abundance and diversity of the Syllidae}

Syllidae was the most abundant polychaete family of the upper rocky shore at Torre Guaceto, contributing 20 and $9 \%$ of the total macrofaunal abundance at 5 and $1.5 \mathrm{~m}$ depths, respectively. Thus, syllid abundance was comparable to the abundances of Crustacea, Mollusca and Nematoda in the study area (see Fig. 4). Syllidae are small to medium-sized polychaetes and their contribution to the standing biomass of macrofauna is generally low. However, small size usually implies short life cycles and fast biomass turnover (Giangrande et al. 2005), suggesting that the contribution of Syllidae to ecosystem functioning may be large, and thus it deserves further attention. Although based on a single sampling occasion, my data showed unusually large values of syllid abundance on shallow subtidal reefs, much larger than those found in neighbouring areas at similar depth and in other Mediterranean MPAs (Fraschetti et al. 2002, Corriero et al. 2004, Musco et al. 2004, 2009). These results reinforce the view that syllids are exceptionally abundant at Torre Guaceto (Giangrande et al. 2004).

High diversity is another feature of the syllid assemblages at the study site. The species recorded in the present study constitute $21 \%$ of the syllid species listed in ERMS (European Register of Marine Species), and 32, 47 and $56 \%$ of the species known for the Italian, Adriatic and South Adriatic coasts, respectively (Castelli et al. 2008). Collectively, the species recorded in my study include $25 \%$ of the known species for the whole Mediterranean (Musco \& Giangrande 2005). However, similar 'hot spots' of syllid diversity have been documented in other Mediterranean areas (e.g. Mikac \& Musco 2010), including other MPAs (author's unpubl. data). These findings indicate that the syllids deserve special attention when estimating patterns of macrofaunal abundance and diversity of hardbottom marine environments, but this will require considerable taxonomic effort.

The identification of species not previously found in the Adriatic Sea and along the Italian coast (the latter site including Miscellania dentata from a preliminary survey) confirms the importance of continuing taxonomic and ecological research even in traditionally well-studied areas (Musco \& Giangrande 2005). Moreover, among the new records, Erinaceusyllis serratosetosa is on the Mediterranean alien species list (Zenetos et al. 2010), and Sphaerosyllis boeroi deserves special attention since it was only recently described for the Ionian Sea and Cyprus 
(Musco et al. 2005), but it is also among the most abundant species at $5 \mathrm{~m}$. These outcomes stress the importance of taxonomy in environmental studies (Terlizzi et al. 2003, Musco et al. 2009, 2011).

\section{Syllid distribution pattern}

Spatial variables are commonly used as covariates in studies aimed at describing spatial variability in assemblages (e.g. Legendre \& Legendre 1998), and are also recommended in impact studies when potential confounding factors are recognized (Benedetti-Cecchi \& Osio 2007). In the present study, using or not using protection level (or isolation) as a covariable in the PERMANOVAs produced similar outcomes, while covariate effects in the univariate analyses were not large enough to modify the general pattern depicted by the ANOVAs. Hence, these factors (i.e. protection level and isolation) appeared to be of little importance in driving variation in syllid assemblages. Spatial heterogeneity in species composition and variability in species abundances are typical of benthic marine assemblages, as a consequence of the interplay of various abiotic and biotic processes operating at different spatial scales and depths (e.g. Benedetti-Cecchi et al. 2000, Therriault \& Kolasa 2000, Sousa 2001). At Torre Guaceto, Syllidae were more diverse at $5 \mathrm{~m}$ depth, while total abundance did not differ between depths, in agreement with results reported elsewhere (Mikac \& Musco 2010). On the other hand, the multivariate analysis showed a high degree of horizontal and vertical variability in assemblage structure. Using samples of small size $\left(100 \mathrm{~cm}^{2}\right.$ instead of the standard $400 \mathrm{~cm}^{2}$ as typically employed in the Mediterranean; Fraschetti et al. 2002) might have influenced the observed variability. However, the residual mean squares obtained from the multivariate analyses (PERMANOVA) of the present study were lower than those reported for syllid assemblages sampled at a similar depth in a nearby area using a larger number of $400 \mathrm{~cm}^{2}$ samples (Musco et al. 2009). This suggested that spatial variation was not inflated by the use of small sampling units. Instead, my results highlighted the interactive nature between the horizontal pattern of assemblage variation and depth (see also Terlizzi et al. 2007 for similar outcomes in other assemblages). On one hand, the large amount of alongshore variation observed at $1.5 \mathrm{~m}$ depth was a consequence of variation in both species composition and abundance, whereas syllid assemblages appeared more homogeneous at $5 \mathrm{~m}$ depth. On the other hand, the dissimilarity among assemblages at 1.5 and $5 \mathrm{~m}$ was mostly due to differences in species abundance rather than composition between depths. Some of the dominant species at $1.5 \mathrm{~m}$ have opportunistic reproductive traits. In fact, the species contributing most to the observed variation, Exogone naidina, reproduces for a large part of the year (Gherardi et al. 2005). These observations suggest that the vertical distribution patterns of the syllid assemblages may be influenced, at least in part, by peculiarities of specific reproductive strategies (Giangrande 1990).

\section{Association with dominant macrobenthic species}

I used dry weight to quantify the abundance of macrobenthic species, a variable that is commonly used to characterize species dominance in benthic assemblages (Cavanaugh et al. 2010, Sala et al. 2011). I tested the hypothesis that syllid distribution related significantly to the abundance of dominant, habitat-forming macrobenthic species, such as the articulated coralline alga Amphiroa sp., which was dominant at $1.5 \mathrm{~m}$ depth. Unexpectedly, I found no significant relationship between this alga and syllid distribution, in contrast to observations elsewhere (Abbiati et al. 1987, Serrano et al. 2006). Geography and habitat dissimilarity might be at the base of the differences between the present study and that of Serrano et al. (2006), who concluded that variation in abundance of habitat-forming taxa is one of the most important factors influencing the distribution of Syllidae along the Atlantic Iberian coast. However, my results are in agreement to those reported by Fraschetti et al. (2002), who found large spatial variation in polychaete assemblages associated with Cystoseira amentacea at $1.5 \mathrm{~m}$ depth $(50 \%$ of which were Syllidae), despite the apparent homogeneity of the algal substratum. Moreover, the hypothesis that sediment-entrapping algae might represent suitable habitats for the Syllidae (Giangrande 1988, Serrano et al. 2006) is not supported by the present results.

While there was no significant relationship with the dominant habitat formers, syllid assemblages varied significantly with less structurally complex species, such as the brown alga Dictyota dichotoma and the green alga Halimeda tuna. These results require further scrutiny, as does the significant correlation between the abundance of other macrofaunal taxa (i.e. sabellids, decapods and eunicids), and the variation in syllid assemblages. The present data does not show whether trophic interaction affects the abundance and distribution of syllid species. Never- 
theless, predation by crustaceans has been suggested as the possible cause of the high diversity and low abundance of polychaete assemblages associated with Posidonia oceanica meadows (Gambi et al. 1995), and evidence suggests that syllids might indeed prey on sabellids (Lepore et al. 2006). The outcomes of the DISTLM-forward analysis, however, call for further research on the feeding habit and trophic relationships among syllids and associated macrofauna. Furthermore, the interaction among syllid species might be responsible for part of the assemblage variability. For example, there is evidence from gut content analyses that specimens of Salvatoria clavata from Torre Guaceto fed on juveniles of Exogone naidina (author's unpubl. data). The integration of taxonomy and ecology could help to uncover the causes of variation in macrofauna assemblages in general-and Syllidae in particularand ultimately to address the question of how so many similar and abundant species can coexist in such a limited space.

Acknowledgements: The editorial supervision of L. Benedetti-Cecchi and constructive criticism of 3 anonymous reviewers improved the manuscript significantly. Dr. A. Ciccolella (Director of the Torre Guaceto MPA management body) kindly permitted this research and provided technical support. I have profited from discussions with F. Badalamenti, S. Fraschetti, A. Terlizzi, T Vega Fernandez and F. Boero. My friends M. Licciano, B. Mikac and M. Tataranni gave valuable comments and S. Damiano supported field operations. Thanks to H. Main for kindly revising the English, and to my friend and tutor A. Giangrande for teaching and support.

\section{LITERATURE CITED}

Abbiati M, Bianchi CN, Castelli A (1987) Polychaete vertical zonation along a littoral cliff in the west Mediterranean. PSZN I: Mar Ecol 8:33-48

Anderson MJ (2003) DISTLM forward: a FORTRAN computer program to calculate a distance-based multivariate analysis for a linear model using forward selection. Department of Statistics, University of Auckland

Anderson MJ, Millar RB (2004) Spatial variation and effects of habitat on temperate reef fish assemblages in northeastern New Zealand. J Exp Mar Biol Ecol 305:191-221

Anderson MJ, ter Braak CJF (2003) Permutation tests for multifactorial analysis of variance. J Statist Comput Simulation 73:85-113

Anderson MJ, Gorley RN, Clarke KR (2008) PERMANOVA+ for PRIMER: guide to software and statistical methods. PRIMER-E, Plymouth

Benedetti-Cecchi L (2001) Variability in abundance of algae and invertebrates at different spatial scales on rocky sea shores. Mar Ecol Prog Ser 215:79-92

Benedetti-Cecchi L, Osio CG (2007) Replication and mitigation of effects of confounding variables in environmental impact assessment: effect of marinas on rocky-shore assemblages. Mar Ecol Prog Ser 334:21-35
Benedetti-Cecchi L, Bulleri F, Cinelli F (2000) The interplay of physical and biological factors in maintaining midshore and low-shore assemblages on rocky coasts in the north-west Mediterranean. Oecologia 123:406-417

Castelli A, Bianchi CN, Cantone G, Çinar ME and others (2008) Annelida Polychaeta. In: Relini G (ed) Checklist della flora e della fauna dei mari italiani. I. Biol Mar Medit 15(Suppl 1):323-373

> Casu D, Ceccherelli G, Curini Galletti M, Castelli A (2006) Short-term effects of experimental trampling on polychaetes of a rocky intertidal substratum (Asinara Island MPA, NW Mediterranean). Sci Mar 70:179-186

Cavanaugh KC, Siegel DA, Kinlan BP, Reed DC (2010) Scaling giant kelp field measurements to regional scales using satellite observations. Mar Ecol Prog Ser 403: $13-27$

Çinar ME, Ergen Z (2002) Faunistic analysis of Syllidae (Polychaeta: Annelida) from the Aegean Sea. Cah Biol Mar 43:171-176

Çinar ME, Gönlügür-Demirci G (2005) Polychaete assemblages on shallow-water benthic habitats along the Sinop Peninsula (Black Sea, Turkey). Cah Biol Mar 4: 253-263

> Corriero G, Gherardi M, Giangrande A, Longo C, Mercurio M, Musco L, Nonnis Marzano C (2004) Inventory and distribution of hard bottom fauna from the Marine Protected Area of Porto Cesareo (Ionian Sea): Porifera and Polychaeta. Ital J Zool 71:237-245

Fanelli G, Piraino S, Belmonte G, Geraci S, Boero F (1994) Human predation along Apulian rocky coasts (SE Italy): desertification caused by Lithophaga lithophaga (Mollusca) fisheries. Mar Ecol Prog Ser 110:1-8

> Fraschetti S, Giangrande A, Terlizzi A, Della Tommasa L, Miglietta MP, Boero F (2002) Spatio-temporal variation of hydroids and polychaetes associated to Cystoseira amentacea (Fucales, Phaeophyceae): a regional scale approach. Mar Biol 140:949-957

> Fraschetti S, Terlizzi A, Benedetti-Cecchi L (2005a) Patterns of distribution of marine assemblages from rocky shores: evidence of relevant scales of variation. Mar Ecol Prog Ser 296:13-29

> Fraschetti S, Terlizzi A, Bussotti S, Guarnieri G, D'Ambrosio P, Boero F (2005b) Conservation of Mediterranean seascapes: analyses of existing protection schemes. Mar Environ Res 59:309-332

Fresi E, Colognola R, Gambi MC, Giangrande A, Scardi M (1983) Ricerche sui popolamenti bentonici di substrato duro del Porto di Ischia. Infralitorale fotofilo: Policheti. Cah Biol Mar 24:1-19

Fresi E, Colognola R, Gambi MC, Giangrande A, Scardi M (1984) Ricerche sui popolamenti bentonici di substrato duro del Porto di Ischia. Infralitorale fotofilo: Policheti (II). Cah Biol Mar 25:33-47

Gambi MC, Giangrande A, Martinelli M, Chessa LA (1995) Polychaetes of a Posidonia oceanica bed off Sardinia (Italy) - spatiotemporal distribution and feeding guild analysis. Sci Mar 59:129-141

> Gherardi M, Mastrodonato M, Sion L, Musco L, Lepore E, Sciscioli M, Giangrande A (2005) Reproduction activity of Exogone naidina (Polychaeta: Exogoninae) in a population from the Apulian coast (Adriatic Sea). Mar Biol 147:197-203

Giangrande A (1988) Polychaete zonation and its relation to algal distribution down a vertical cliff in the western Mediterranean (Italy): a structural analysis. J Exp Mar 
Biol Ecol 120:263-276

Giangrande A (1990) Distribution and reproduction of syllids (Annelida, Polychaeta) along a vertical cliff (West Mediterranean). Oebalia 16:69-85

Giangrande A, Licciano M, Pagliara P (2000) The diversity of diets in Syllidae (Annelida: Polychaeta). Cah Biol Mar 41: 55-65

Giangrande A, Delos AL, Fraschetti S, Musco L, Licciano M, Terlizzi A (2003) Polychaete assemblages along a rocky shore on the South Adriatic coast (Mediterranean Sea): patterns of spatial distribution. Mar Biol 143:1109-1116

Giangrande A, Delos AL, Musco L, Licciano M, Pierri C (2004) Polychaete assemblages of rocky shore along the South Adriatic coast (Mediterranean Sea). Cah Biol Mar 45:85-95

Giangrande A, Licciano M, Musco L (2005) Polychaetes as environmental indicators revisited. Mar Pollut Bull 50: $1153-1162$

Guidetti P (2006) Marine reserves reestablish lost predatory interactions and cause community changes in rocky reefs. Ecol Appl 16:963-976

Legendre P, Legendre L (1998) Numerical ecology, 2nd English edn. Elsevier Science, Amsterdam

Lepore E, Sciscioli M, Mastrodonato M, Gherardi M, Giangrande A, Musco L (2006) Sperm ultra-structure and spermiogenesis in Syllis krohni (Polychaeta: Syllidae), with some observations on its reproductive biology. Sci Mar 70:585-592

Licher F (1999) Revision der Gattung Typosyllis Langerhans, 1879 (Polychaeta: Syllidae). Morphologie, Taxonomie und Phylogenie. Abh Senckenb Natforsch Ges 551: $1-336$

> McArdle BH, Anderson MJ (2001) Fitting multivariate models to community data: a comment on distance-based redundancy analysis. Ecology 82:290-297

Mikac B, Musco L (2010) Faunal and biogeographic analysis of Syllidae (Polychaeta) from Rovinj (Croatia, northern Adriatic Sea). Sci Mar 74:353-370

Musco L, Giangrande A (2005) Mediterranean Syllidae (Annelida: Polychaeta) revisited: species diversity, biogeography and faunal fidelity to environmental features. Mar Ecol Prog Ser 304:143-153

Musco L, Cavallo A, Giangrande A (2004) I sillidi (Annelida, Polychaeta) del litorale brindisino: possibilita' di un loro impiego come indicatori di qualità dell'ambiente. Thalassia Salent 27:161-174

Musco L, Çinar ME, Giangrande A (2005) A new species of Sphaerosyllis (Polychaeta: Syllidae Exogoninae) from the coasts of Italy and Cyprus (eastern Mediterranean Sea). Ital J Zool 72:161-166

Musco L, Terlizzi A, Licciano M, Giangrande A (2009) Taxonomic structure and the effectiveness of surrogates in environmental monitoring: a lesson from polychaetes. Mar Ecol Prog Ser 383:199-210

Editorial responsibility: Lisandro Benedetti-Cecchi, Pisa, Italy
Musco L, Lepore E, Gherardi M, Sciscioli M, Mercurio M, Giangrande A (2010) Sperm ultrastructure of three Syllinae (Annelida, Phyllodocida) species with considerations on syllid phylogeny and Syllis vittata reproductive biology. Zoomorphology 129:133-139

Musco L, Mikac B, Tataranni M, Giangrande A, Terlizzi A (2011) The use of coarser taxonomy in the detection of long-term changes in polychaete assemblages. Mar Environ Res 71:131-138

Nygren A (2004) Revision of Autolytinae (Syllidae: Polychaeta). Zootaxa 680:1-314

Riedl R (1991) Fauna e flora del Mediterraneo. Muzzio F (ed) Dalle alghe ai mammiferi: una guida sistematica specie che vivono nel Mar Mediterraneo. Scienze naturali, Padova

Sala E, Kizilkaya Z, Yildirim D, Ballesteros E (2011) Alien marine fishes deplete algal biomass in the Eastern Mediterranean PLoS ONE 6(2): e17356 doi:10.1371/journal. pone. 0017356

San Martín G (2003) Annelida, Polychaeta. II. Syllidae. In: Ramos MA, Tercedor JA, Bellés I, Ros X and others (eds) Fauna Iberica, Vol 21. Museo Nacional de Ciencias Naturales, CSIC, Madrid; p 1-554

Serrano A, San Martín G, López E (2006) Ecology of Syllidae (Annelida: Polychaeta) from shallow rocky environments in the Cantabrian Sea (South Bay of Biscay). Sci Mar 70: 225-235

Sousa WP (2001) Natural disturbance and the dynamics of marine benthic communities. In: Bertness MD, Gaines SD, Hay ME (eds) Marine community ecology. Sinauer Associates, Sunderland, MA

Tena J, Capaccioni-Azzati R, Torres-Gravila FJ, Garcia-Carrascosa AM (2000) Polychaetes associated with different facies of the photophilic algal community in the Chafarinas archipelago (SW Mediterranean). Bull Mar Sci 67: $55-72$

Terlizzi A, Bevilacqua S, Fraschetti S, Boero F (2003) Taxonomic sufficiency and the increasing insufficiency of taxonomic expertise. Mar Pollut Bull 46:556-561

Terlizzi A, Anderson MJ, Fraschetti S, Benedetti-Cecchi L (2007) Scales of spatial variation in Mediterranean subtidal sessile assemblages at different depths. Mar Ecol Prog Ser 332:25-39

Therriault TW, Kolasa J (2000) Explicit links among physical stress, habitat heterogeneity and biodiversity. Oikos 89: 387-391

Witman JD, Dayton PK (2001) Rocky subtidal communities. In: Bertness MD, Gaines SD, Hay ME (eds) Marine community ecology. Sinauer Associates, Sunderland, MA

Zenetos A, Gofas S, Verlaque M, Çinar ME and others (2010) Alien species in the Mediterranean Sea by 2010. A contribution to the application of European Union's Marine Strategy Framework Directive (MSFD). I. Spatial distribution. Medit Mar Sci 11:381-493

Submitted: May 9, 2011; Accepted: April 6, 2012

Proofs received from author(s): July 25, 2012 